\title{
The Historical Development Of Ikebana
}

Machiko Nakayama, Independent scholar

Penang, Malaysia

machikopenang@googlemail.com

(C) 2018 University of Malaya. This journal is licensed under the terms of the Creative Commons Attribution (CC BY-NC-ND) (https://creativecommons.org/licenses/by-nc$\mathrm{nd} / 4.0 /$ )

Received 08 August, 2018; Accepted 4 December, 2018; Published 31 December, 2018.

\begin{abstract}
This article is an attempt to focus on the origin of ikebana, tatehana (standing branch or flower) style and to examine the process of the historical development of ikebana. First, we pay attention to the fact that the treetop of a big tree is brought into the house and is put up in a flower vase and decorated in the tokonoma (wall niche) even today after having been cut in the rituals of the mountain divinity, then we will examine what kind of effect the belief in big trees had on the formalization of tatehana style, established in the Muromachi period (1338-1573). We will examine how the tatehana style was formalized, how the tatehana style developed into rikka (standing branch or flower) style, established in the early Edo period (17th century), how seika or shoka (standing branch or flower) style in the latter part of Edo period (18th century) evolved from rikka style through the historical development of ikebana. Finally, we will conclude that this is ikebana.
\end{abstract}

Keyword: Ikebana, tatehana, the mountain divinity, the central branch, the central axis, the tokonoma space.

\section{Definition of Ikebana}

Ikebana is a traditional Japanese cut-plant arrangement using branches, leaves, and flowers which are placed in containers or vases filled with water. These are then displayed in a room. At various periods in Japanese history, ikebana was called by different names, including tatehana 立花 (standing branch or flower) from the late 15th to the late 16th century, nageire なげ入 [toss or throw in] from the late 15th century onward, rikka 立華 (standing branch or flower) from the 17th century onward, seika or shoka 生花 (standing branch or flower) from the 17th-18th century onward, bunjinbana 文人花 [literati flowers] in the 18th and 19th century, as well as moribana 盛花 [piled flowers] from the 19th century onward. Today these arrangements are generically called ikebana. First, this paper will focus on the origin of ikebana, tatehana which was established during the Muromachi period (1338-1573).

\section{The Starting Point of Ikebana-Tatehana}


There are various opinions about the origin of ikebana, tatehana. The Japanese scholar of religious mountains, Gorai Shigeru, writes in Yama no Shukyo-Shugen-do Kogi 山の 宗教-修験道講義 [Mountain Religion-The Lecture of Shugen-do] (1992) as follows:

\begin{abstract}
Shinbutsu ni sasageruhana wa Tokiwagi aruiwa Maki no eda de aru. Mata Hana to iuno wa ki no ichiban saki wo hana to iu. Ichiban sentan ni hana wa daitai tukumono desu kara soreni kami ga yadoru to iu imi desu. Dakara kami no yorishiro ni narumono wo ageru. Ageta tokoro ni kami ga oritekite matsuri wo ukeru. Kore ga Tatehana, Hanadate to iu monodesu. [The plant offering to the Shinto divinities and Buddha is a branch of tokiwagi 常磐木 (evergreen) or maki 槙 (yew plum pine; Podocarpus macrophyllus). In addition, the 'nose' of a tree is termed as hana 鼻 and, generally, flowers sprout from the tip of the tree, therefore, the term hana 花 (flower) also signifies the object that the mountain divinity is said to live in after descending from the sky. People would hold up the object to the sky for the mountain divinity to descend upon and receive the offered prayers. This is tatehana 立花 or hanatate 花立 (standing a branch straight)]. (Gorai, 1992a, own translation)
\end{abstract}

Based on this statement, clues as to the origin of tatehana are as follow:

- the plant offering to the Shinto divinities and Buddha is a branch of an evergreen tree.

- the term hana (flower/nose) signifies the object that the mountain divinity is said to dwell in after descending from the sky.

- the object that was held up was where the divine spirit receives the offered prayers.

\title{
3. The Shinto Rituals of Standing a Branch Straight (Tobusadate) for the Mountain Divinity
}

The existence of the Shinto rituals of standing a branch straight called tobusadate 鳥総立 $\tau$ was found while researching tatehana 立花. The Shinto rituals of tobusadate are still held today in the Nagano Prefecture. It is thought that the people of Japan have worshiped the mountain divinity by performing the customary practices of tobusadate since ancient times (Figure 1). 


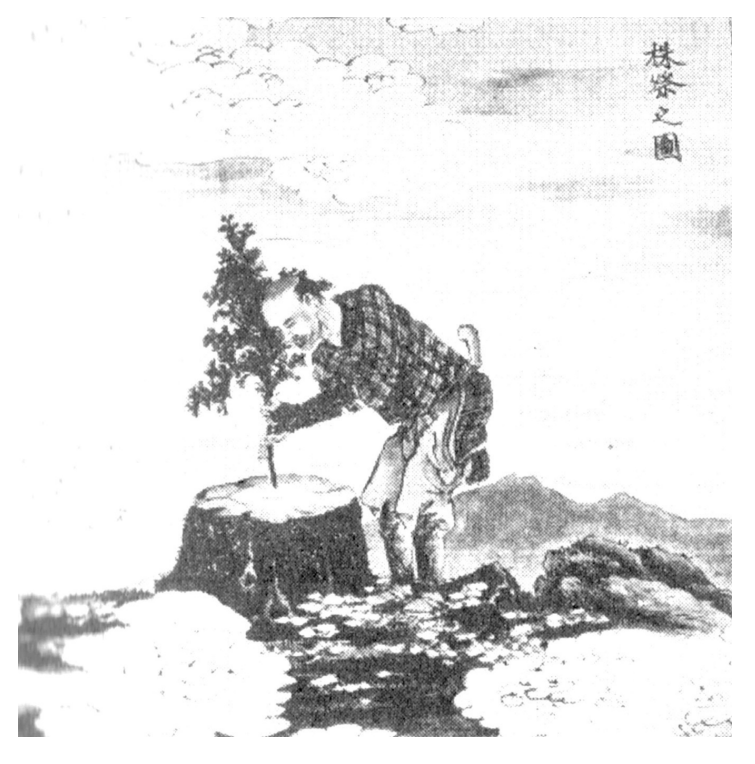

Figure 1. Tobusadate 鳥総立 $\tau$ in Kabumatsuri-no-Zu 株祭之圖 [Figure of Tree Stump Festival] drawn in the Edo period. Source: KisoshikiBatsuboku-Unzai-Zue 木兽式伐木運材圖 絵 [The Document of Picture Depicting the Logging and the Log Hauling of Kiso] by Nagano Regional Forestry Office published in 1954.

Figure 2 shows a photograph of the tobusadate ritual taken in the Higashimata national forest when the rite of Bassai 伐採 or cutting trees was performed during the Onbashira-sai 御柱祭 festival dedicated to the mountain divinity that was held in May 2015. According to the mountain dwellers who participated in the Onbashira-sai festival of Shimosuwa, the customary practice of tobusadate has been performed in the forests of Shimosuwa in the Nagano Prefecture since ancient times. As for the manners and customs of tobusadate, an account of the ceremonial manners dedicated to the mountain divinity has been handed down from long ago. Furthermore, a similar story surrounding Mt. Yatsugatake in the Suwa District that has also been handed down to the Suwa people suggests a close relationship between the tobusadate 鳥総立 $て$ and the tatehana 立花. After the ceremony of cutting a big fir tree in 2015, the mountain dwellers participated in the Onbashira-sai festival and brought the treetop of the tree crown, called uraho 梢穂, to a house as a memorial object where it was put into a flower vase and placed to decorate the tokonoma 床の間 space (Figure 3). It can be inferred from these customary practices that this treetop is highly likely to be the origin of tatehana established in the Muromachi period (1338-1573)(Gorai, et al., 1981b; Miyake, 2004b). 

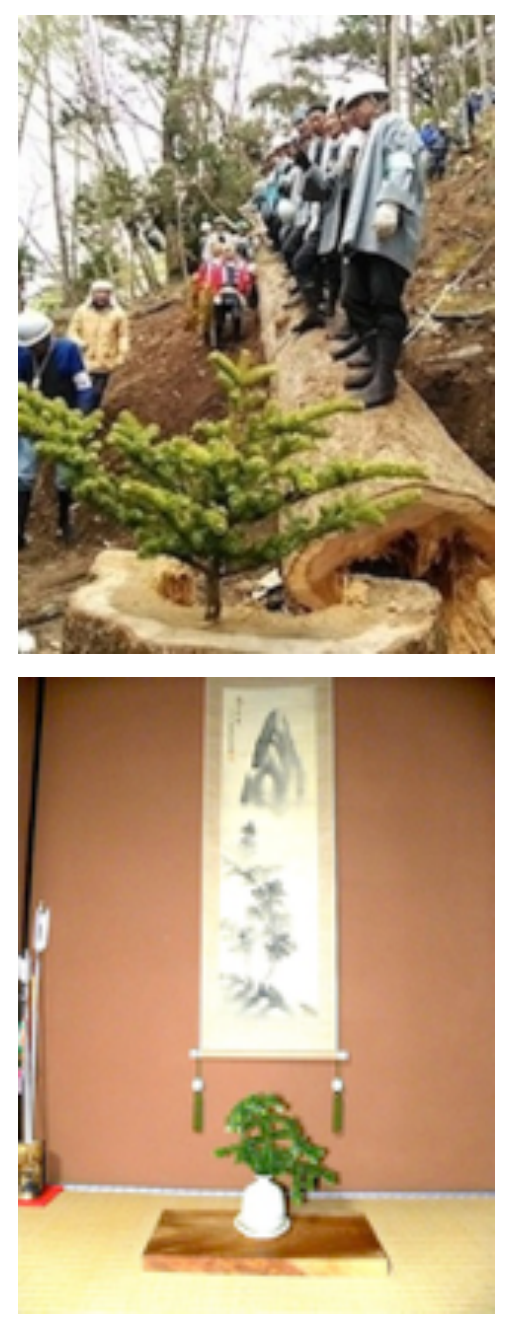

Figure 2. The Shinto rituals of tobusadate 鳥総立 after cutting the big tree in May, 2015. See the cut-fir treetop in front of this photograph. By permission of Komatsu Naoto.

Figure 3. An example of the tobusadate 鳥総立て, called uraho 梢穂, put up in a flower vase placed in the tokonoma space in May, 2015. By permission of Yatsugatake Gakurokusoba Dayori.

\section{How Tatehana was Formalised}

In this section, we will examine the essence of tatehana in detail and discuss its development.

\subsection{The latent period of tatehana during the Nanbokucho period (1336-1392)}

In Origins of Ikebana Philosophy published in 1999, I defined tatehana as the style of cut-plant arrangement in which the focus is on a standing centre stem. In the early 14th century it was a common practice to use karamono- $\operatorname{dog} u$ 唐物道具 or imported goods from China, as decorative items in the residences of noblemen. Mitsugusoku 三具足 (Figure 4), translated as a set of three items on the Buddhist altar table - a candle, an incense burner and a flower vase-were often placed in front of sacred scrolls (Nishibori, 1967; Kudo, 1987). During the Nanbokucho period, also known as the period of the Northern and Southern Courts, oshi-ita 押板 (Figure 5), the original form 
of tokonoma 床の間 (Figure 6), a fixed wall niche was created (Ikebana Sogo Daijiten [Ikebana General Encyclopaedia], 1980).
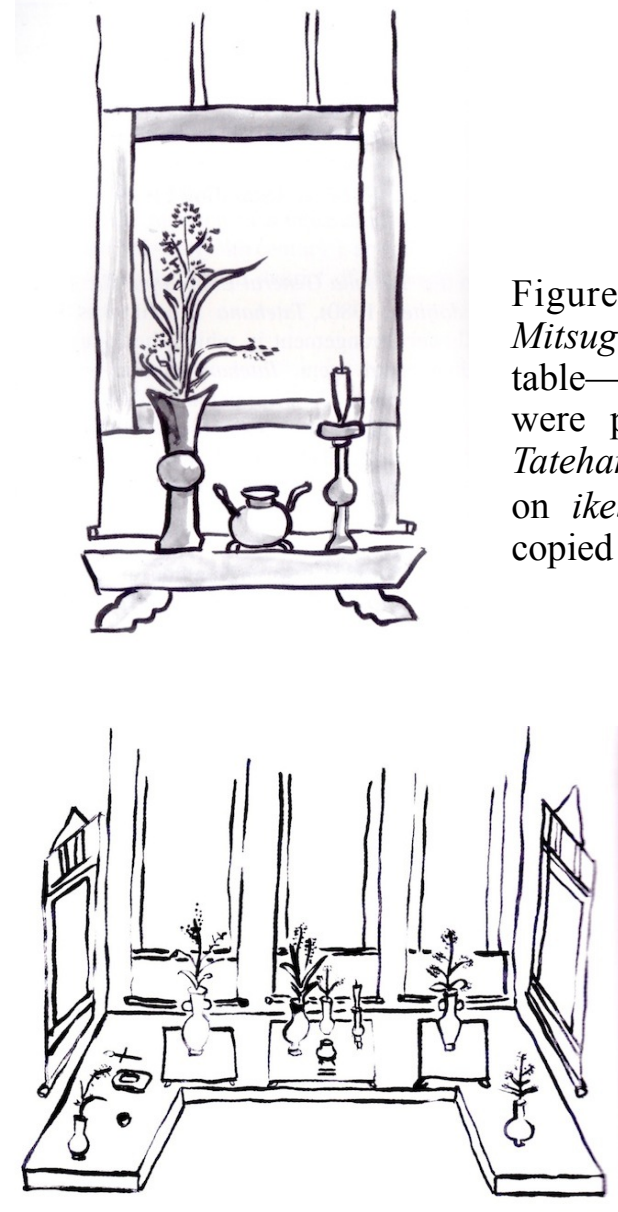

Figure 5. The drawing of oshi-ita 押板 (floor board). Oshi-ita is the original form of tokonoma 床の間. This tatehana was arranged in the Shogun's residence in the 15th century. This board is a step towards the establishment of tokonoma. Threedimensional drawing based upon the twodimensional drawing of Zashiki Kazari no Shidai 座敷飾之次第 (the 15th century document of a set of decorative features) by Fujiwara Tadaoki. Source: Sendenshou 仙伝 抄 [the book of secrets on ikebana] by Tanaka Jutaro, Okada Kozo published in 1981. The illustration is hand copied by the author.

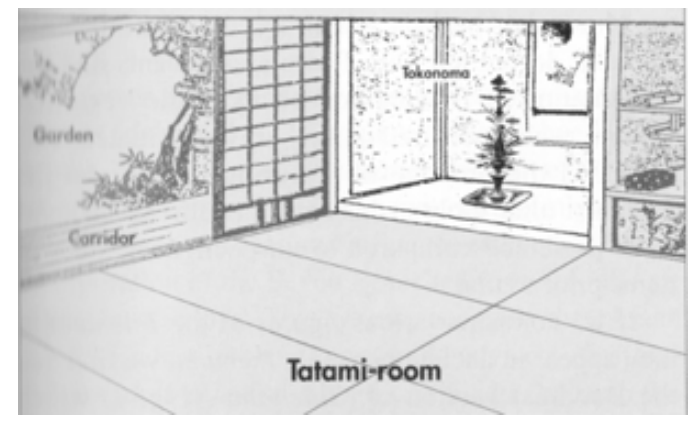

Figure 6. The drawing of tokonoma 床の間 (wall niche). The tokonoma is the most important space in the traditional house. An honoured guest or a highly respected person usually sits in front of it. The decoration of the tokonoma varies with each season. Source: Origins of Ikebana Philosophy by Machiko Nakayama published in 1999. 
In the Muromachi period, another form of decoration, different from the room decoration, appeared. People collected flowers and plants as an offering to the Weaver Star (the Lyre's Vega) during the Tanabata or Shichiseki 七夕, that is the festival of the Weaver on the seventh day of the seventh month. In the early Muromachi period, the events of Shichiseki Horaku 七夕法楽 [flowers placed for drinking party to enjoy the view] were continually held on July 7th in the lunar calendar (Nakayama, 2005). As a result of this festival, imported vases from China (karamono) also became popular at the Imperial Court (Ooi, 1968; Hosokawa, 1985).

It was written in Kanmon-gyoki 看聞御記 (a 15th century diary of Prince Fushimi-nomiya Sadafusa Shinno) as follows:

Hana awase ha Fushimi-no-miya Sadafusa Shinno no gosho de Tatehana Horaku no aida hobo itsumo okonawareteita node ryukosuru koto ni natta. Eikyo yo ne'n no Tatehana Horaku no aida, kaisho wa rokuju go no kabin ni hana ga kazarareta.[The hana-awase 花合せ [a contest to judge the quality of flowers] was performed mostly during the Tatehana Horaku 立花法楽 in the prince imperial's palace and became popular, and during the Tatehana Horaku of 1432, the kaisho 会所 [gathering-place] was decorated with sixtyfive flower vases full of blooming flowers]. (Hanawa, 1911, own translation)

Some of the events held at the court were called kiku-awase 菊合せ [a contest to judge the quality of chrysanthemums], senzai-awase 前栽合せ [a contest to judge the quality of garden plants and trees], and hana-awase where people came together bringing chrysanthemums, garden trees and plants, and cut flowers were divided into two teams. There remain some slightly formalised drawings of tatehana in Kaoirai no Kadensho 花王以来の花伝書, which is a 15 th century manuscript on ikebana, written by Ikenobo Kazoin in 1486 (Tanaka \& Okada, 1981).

According to this manuscript, trees, leaves, and flowers arranged in a vase came to be displayed in a zashiki 座敷 [Japanese style tatami-floored room] or a drawing room. Among written records, we found descriptions of the tatehana forms from which we can recall the beginnings of tatehana as mentioned above (Hanawa, 1899). After the Onin War 応仁の乱 (1467-1477), the seven branched standing form, tatehana, appeared. Tatehana is its proper name, but this form is also commonly known as Nanatsu-eda or Nanaeda 七枝 [Seven Branches].

Due to the 10 years of the Onin War, most illustrations were lost (Nagahara, 1977). It is impossible to ignore the tatehana in any attempt at examining the traditional practices of ikebana (Nakayama, 2001). However, in one of the 15th century manuscripts on the theory of ikebana, a prototype of the tatehana form called Nanaeda 七枝 was found. One example of this prototype of tatehana can be seen in the diagram of a Nanaeda entitled Tenyorikudaru-Hana-no-Ezu 天ヨリ下ル花之繪圖 [Figure of Flower Descending from the Heaven] (Figure 7) in Kegon Hiden no Daiji 華厳秘伝之大事, which is a 15th century manuscript of Kegon on ikebana (Zoku Kado Kosho Shusei 1 [Collection of 
Writing on the Secrets of Way of Japanese Flower Arrangement Continued Vol.1], 1972).

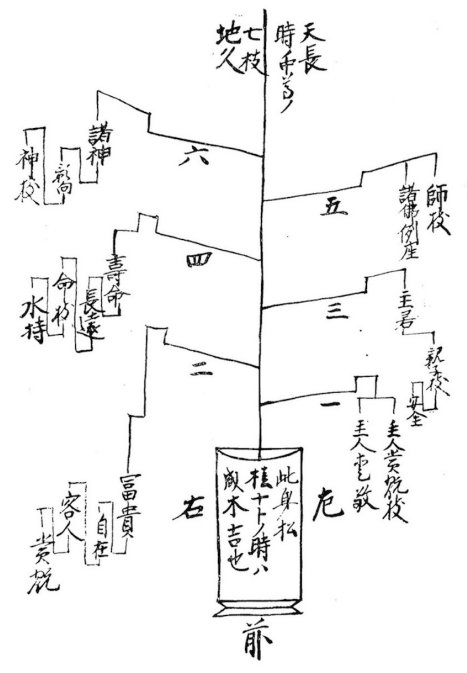

Figure 7. An example of the tatehana diagram entitled Tenyorikudaru-Hana-no-Ezu 天ョリ下ル花之繪 圖 [Figure of Flower Descending from the Heaven]. Source: Kegon Hiden no Daiji 華厳秘伝之大事 (a 15th century manuscript of Kegon on ikebana) by Ikenobo Kazoin 池坊花蔵院 written in 1487.

This tatehana called Busshin-no-Hana 仏神の花 [Flower of Buddha and Shinto Divinities] is described as follows:

Kegon Hiden no Daiji no sozu niwa hana no hidari no go no eda ni Shi-eda, Shobutsuretsuza to ari, hana no migi no roku no era ni Shoshin, yoko /Yogo, Kami-eda no meishou ga fusareteiru. Kore wa chokushin ni tateta shokubutsu ni buttshin ga yadoru to iu furuku kara no kangaekata kara kuru mono de aru. Kono kangaekata wa rikka nimo keishosarete iru. [In the figure of Kegon Hiden no Daiji 華厳秘伝之大事, the fifth 五 branch (on the left as one faces it), is titled 'Shi-eda' 師枝 [branch of master] and 'Shobutsu-retsuza' 諸佛列座 [various Buddha sitting side by side]. The sixth 六 branch (on the right as one faces it), was titled 'Shoshin, Yoko or Yogo' 諸神影向 [the advent of various Shinto divinities], 'Kami-eda' 神枝 [branch of Shinto divinity]. This idea came from the traditional practice that the Shinto divinities and Buddha descend from the heaven to the standing plants and dwell in there. This was also handed down to rikka 立 華]. (Ikebana Sogo Daijiten [Ikebana General Encyclopaedia], 1980)

We will now examine some tatehana figures in more details and discuss the religious and cultural background and then clarify the traditional practice of tatehana.

An important diagram entitled Tenyorikudaru-Hana-no-Ezu 天ヨリ下ル花之繪圖 [Figure of Flower Descending from the Heaven] representing Shaka Sanzon 釈迦三尊 [Sakyamuni triad]. The source of this diagram is Kegon Hiden no Daiji 華䇜秘伝之大事, which is a 15th century manuscript of Kegon on ikebana by Ikenobo Kazoin 池坊花藏院, written in 1487. 
This diagram (Figure 8) is also known as Tenyorikudaru-Hana-no-Ezu 天ヨリ下ル花之繪圖 [Figure of Flower Descending from the Heaven]. It represents a fan-shaped form and has a central axis connecting the heaven with the earth. At the bottom of this diagram the words sashitome サシトメ [putting up a stick] is written, so we understand this as being fixed at the base. The characters shin 身 [body] and shaka 釈迦 [Sakyamuni] are written on the central branch in the diagram. These characters symbolically represent the body of Sakyamuni, that is the Buddha. Two smaller fan-shaped forms are drawn below this bigger fan-shaped diagram. The characters Fugen 普賢 indicating Samantabhadra (the bodhisattva of universal compassion) are written on the right, while the characters Monju 文殊 referring to Manjusri (the bodhisattva of wisdom and intellect) are written on the left. So we can say that these three diagrams represent symbolic representation of Shaka Sanzon 釈迦三尊 or the Sakyamuni triad, which is an image of the Buddha flanked by two attendants.

It can be deduced from the diagram that this was a religious practice in which the esoteric Buddhist monks of the Kegon 華厳, a sect of Buddhism based on the Avatamsaka Sutra or the Shugen-ja 修験者, the practitioners of the Japanese religion of Shugen-do 修験道, trained on mountains to receive spiritual enlightenment (Kamata, 2002). This practice is called mountain asceticism. They sit down quietly with their back up straight, and conjure an image of Buddha by focusing on the central branch of this diagram (Yamaori, 1993; Yamaori, 1994; Wakamori, 1988; Miyake, 2003). Furthermore, the characters Tencho Chikyu 天長地久 and the number seven (七) are written in the upper part of the central branch. According to the Encyclopaedia of the History of Japanese Manners and Customs (Nihon Huzokushi Jiten, 1979), the term Tencho Chikyu means 'heaven and earth exist forever.' This phrase is extracted from

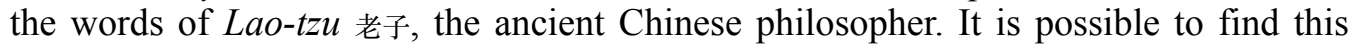
idiom in Taoist ancestral shrines even now. In addition, the characters Nichi-yo 日陽 or Sun Positive and Getsu-in 月陰 or Moon Negative are written in the middle part of the central branch. The Chinese principle of the positive (sun; yang) and negative (moon; in) are synthesised with specifically Japanese philosophies (Murayama, 1992).

It can be argued from this diagram that the tatehana was created by ascetic monks or mountain priests who believed that the Shinto divinities and the Buddha would descend from the heaven to the tip of an evergreen tree and dwelt there. For that reason, this central branch has the central axis connecting the heaven with the earth. 


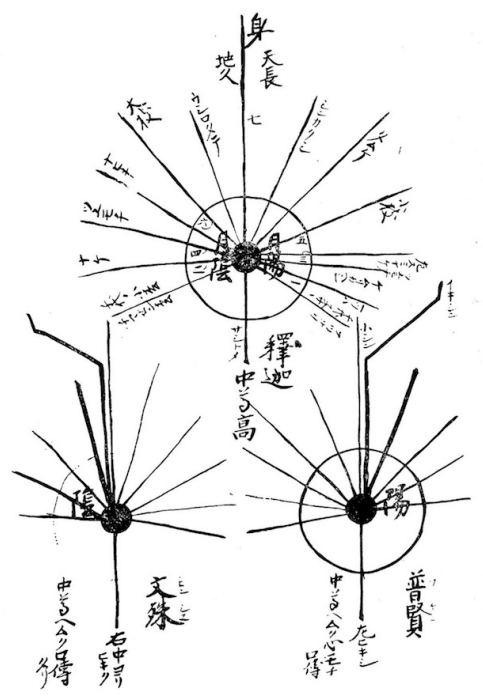

Figure 8. An example of the tatehana diagram entitled Tenyorikudaru-Hana-no-Ezu 天ヨリ下ル花 之繪圖 representing Shaka Sanzon 釈迦三尊 or the Sakyamuni triad. Source: Kegon Hiden no Daiji 華厳秘伝之大事 (a 15th century manuscript of Kegon on ikebana) by Ikenobo Kazoin 池坊花蔵院 written in 1487.

The second diagram to be studied is the tatehana figure representing the Birth of Buddha 誕生伀 by the shugen-ja in the Todaiji Temple. This diagram is found in Kadenshou 花伝抄, which is a manuscript on ikebana, written around the 15 th or 16 th century.

This tatehana (Figure 9) is likened to the physical body of a child prince who will become the Buddha, Siddhartha Gautama. This is because the characters Tenjo Tenge 天上天下 [Heaven and Earth] are written at the top part of the central branch and the characters Yuiga Dokuson 唯我独尊 [Holy am I alone] are written in the right lower part. It is said in the Buddhist idiom that when Buddha was just born, he did not cry but one finger pointed to the heaven, one finger pointed to the earth, at the same time he said 'I am the centre of the universe.' We find that the characters 過去 [past] are connected to lotus seeds by a line, the characters 現在 [present] are tied to the lotus flower and the characters 未来 [future] are tied to the bud of a lotus in this figure. In other words, the the past, present and future are condensed and visualised spatially. It can be imagined that in those days people looked up the large statue of the enlightened Buddha (approximately 16 metres high) at Todai-ji Temple in Nara and felt overwhelmed by comparing it to the small-sized statue of a child prince (about $45 \mathrm{~cm}$ ).

In my book titled 500 Years of Ikebana published in 2013, this type of tatehana representing the Birth of Buddha, which had been practiced since ancient times, was created by ascetic monks, because the shugen-ja of the Tozan 当山 branch (one of main Shugen-do branches) was found to make flower or branches offering to kami [Shinto divinity] and the Buddha at the Todaiji Temple in Nara (Yamaori, 1991). From that, we conclude that the shugen-ja devised this type of tatehana.

The same applies to Ikenobo Jushin'in 池坊住心院 (shugen-ja of the Honzan 本山 branch, another main Shugen-do branch), as it is written in old documents in Koya 高野文書 that Ikenobo Jushin'in was offering flowers at Mt. Koya (Wakayama Prefecture) and devised his own tatehana in the 16th century (Gorai, 1992a). It was also written in one 
of my previous books published in 2013 that there were many shugen-ja involved in the event celebrating the Birth of Buddha throughout Japan (Nakayama, 2013). Besides celebrating the Birth of Buddha, there were also other events such as opening ceremonies marking the climbing of the sacred mountains throughout Japan as well as the memorial ritual to the ancestors in the mountains on the 8th day of the 4th month of the lunar calendar, during which this ritual of offering was carried out (Gorai, et al., 1980b; Gorai et al., 1981a; Miyake, 1991). The sacred mountains were closely connected with the image of the Birth of Buddha since ancient times. There is a picture of a statue of the child prince placed in a tray to celebrate the Birth of Buddha dated to a 12th century scroll marking annual events in Japan.

It is interesting to note that the idea of past, present and future of the Shugen-do, that also worshipped the sacred mountains and believed that the divine spirit dwelt there, is different from the purer teachings of Buddhism. For example, Dewa Sanzan 出羽三山, the three sacred peaks of Dewa (Yamagata Prefecture), is an ancient centre of the Shugen-do practice and pilgrimage. In Dewa Sanzan, Mt. Gassan 月山 $(1,980 \mathrm{~m})$ has been metaphorically likened to the past, Mt. Haguro 羽黑山 $(419 \mathrm{~m})$ to the present and Mt.Yudono 湯殿山 $(1,504 \mathrm{~m})$ to the future (Togawa, 1980). Thus the idea of past, present and future has been expressed in terms of a spatial axis.

Therefore, we can say that the ascetic monks created this vertical standing form of tatehana with the central axis connecting the heaven with the earth.

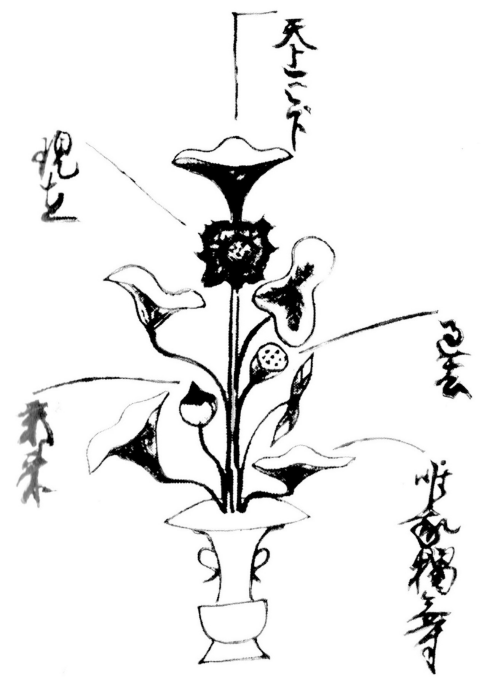

Figure 9. An example of the tatehana figure representing the Birth of Buddha 誕生仏. Source: Kadenshou 花伝抄 (a circa 15th-16th century manuscript on ikebana).

A third example of a tatehana diagram focuses on the central axis by Ikenobo Sen'no 池坊専応. This diagram is taken from Sen'no Kuden 専応口伝, which is a 16th century oral traditions on ikebana, written in 1523.

This is a vertical tatehana form (Figure 10) reshowing a central axis. We see that the character 真 (shin; central branch) overlaps at the top of the central branch with the 
central axis connecting the heaven with the earth. And the characters 小真 or shoshin, referring to the small central branch, are connected at the top of the short central branch by a line in this diagram. Generally speaking, the shin and the shoshin make up centre. The kanji character 真 (shin) means truth in Buddhism and Confucianism. The kanji character 心 (shin) means immaculateness in Shintoism and pure heart in Buddhism, while the kanji character 身 (shin) means a human body as well as the body of Buddha (Ikebana Sogo Daijiten [Ikebana General Encyclopaedia], 1980). Here it indicates a central standing branch representing the central axis of a mountain, because there are the two branches namely mikoshi みこし [looking over] in the middle right and left of this diagram. It is written in Ikebana Sogo Daijiten [Ikebana General Encyclopaedia] (1980) that a 17th century ikebana master, Ikenobo Senko II (二代池坊専 好), expressed the scenery of far mountains by using the term mikoshi 見越 (みこし) in the entry word. In addition, we notice that Ikenobo Sen'no 池坊専応 was, highly likely, a shugen-ja, because it was written in Ikebana Jinbutsushi いけばな人物史 [History of Personage on Ikebana] (1977) by Hojo Akinao that the term Jiju 侍従 also means the name of a position in the shugen-ja. Hojo Akinao also gave this title to Ikenobo Sen'no as his official name 六角堂池坊侍従専応 as is mentioned in Sen'no Kuden written in 1523.

Therefore, we can say that this diagram reflects the mountain worship by Ikenobo Sen'no and shows the establishment of the symbolical tatehana with the central axis connecting the heaven with the earth.

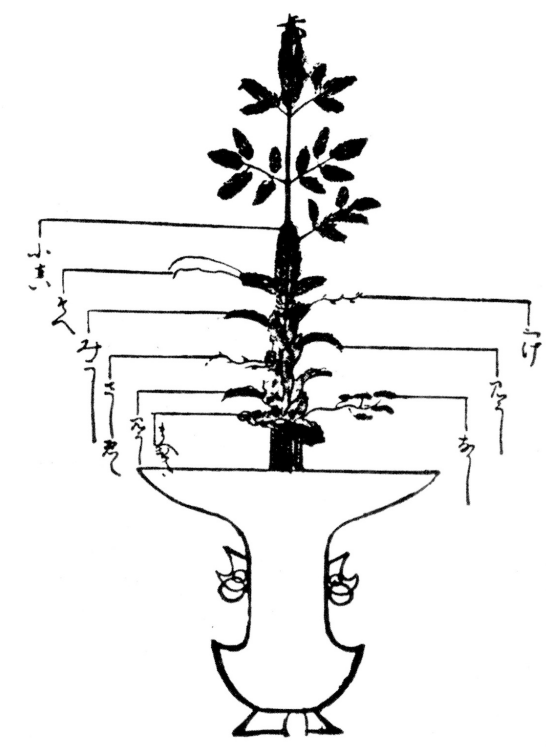

Figure 10. An example of the tatehana diagram representing the central axis of a mountain by Ikenobo Sen'no 池坊専応. Source: Sen'no Kuden 専応口伝 (a 16th century oral traditions on ikebana) written in 1523 .

The fourth tatehana we will look at is a figure of Chuo-no-hana 中央花 or Central Flower (Figure 11) by Sosei 宗清 found in Sosei Kadensho 宗清花伝書, which is a 16th century manuscript on ikebana, written in 1529. 
The image shows a tatehana placed in the middle of a flower base with four legs in Buddhist funeral rites. The kanji characters 四方 (shiho; four directions) were written on the same manuscript. The four-character idiom Syo-Ro-Byo-Shi 生老病死 [birth, aging, sickness, death] was written in Kasho 花書, which is another 16th century manuscript on ikebana. Four descriptions like Hossin 発心 or spiritual awakening, Shugyo 修行 or ascetic practice, Bodai 菩提 or supreme enlightenment, and Nehan 涅然 or Nirvana referring to the Buddha's death were also mentioned in both manuscripts. From the above, it is highly likely that Sosei was a shugen-ja. If so, the four-character idiom suggests the Buddhist legend of four sights (Shimon-Shutsuyu 四門出遊) regarding the four gates handed down by word of mouth in Japan. The four sights refer to four things described in the legend of Gautama Buddha's life. This legend relates as follows:

Aruhi, Shaka wa basha wo kakette okyu no higashi no mon kara tonori ni dekaketa. Sonotoki, Shaka wa yase otoroeta rojin wo mite, hito wa oi wo sakerarenai koto wo shitta. Tsugini, Minami no mon kara dekaketa toki, Shaka wa modae kurushimu byonin wo mita. Sarani, nishi no mon kara dekaketa toki niwa, soshiki no gyoretsu ni deatta. Hito wa ryo byo shi no kurushimi kara nogareru michi wa nainoka. Soshite fukaku nayanda Shaka ga kita no mon kara dekaketa toki, shizuka ni tatazundeiru tabi no shugyosha ni deatta. Kare no Heian'na hyojo wo mite, shaka wa shukke wo ketsuishita to iu.[One day the prince went for a long ride in a horse carriage from the east gate, and he learnt of inevitable aging in life. Then, going from the south gate, he saw a critically sick man. Later, when he went from the west gate, he met a funeral procession. Contemplating the suffering and the way to escape from the four kinds of suffering (birth, aging, sickness, death), he went out from the north gate and met an ascetic monk sitting quietly on the way. It is said that the prince decided to enter the priesthood when seeing this monk's peaceful facial expression]. (Britannica Encyclopaedia, 2014)

In one of my previous books published in 2013, I indicated that the tatehana entitled Chuo-no-hana 中央花 or Central Flower symbolising four Buddhist gates was created by shugen-ja who paid respect to Buddha and the world of Mikkyo Mandara 密教曼余羅 or mandala of esoteric Buddhism. We find that this idea was created as the equivalent of the four gates in the Buddhist legend linked and the four gates of Shugen-do based on Shimon-Shugyo 四門修行 [Ascetic Practice of Four Gates]. The term Shimon-Shugyo refers to the realisation of true enlightenment by going through the four gates. For example, in the Omine Shugen-do 大峰修験道, the four gates were built as Hosshin-mon 発心門 or Gate of Spiritual Awakening, Shugyo-mon 修行門 or Gate of Ascetic Practice, Togaku-mon 等賞門 or Gate of Equality to Bosatsu (one of the Buddhist saints), and Myogaku-mon 妙覚門 or Gate of True Enlightenment. All were built at the entrance of the mountain in Yoshino, along the Omine pilgrimage route up to the Ominesanji 大峰山 寺 Temple, the sacred place at the top of Mt. Yoshino 吉野山 (Gorai et al., 1980a; Gorai et al., 1982). 
So we can say that this figure reflects the sacred mountain worship and has a central branch with the central axis connecting the heaven with the earth.

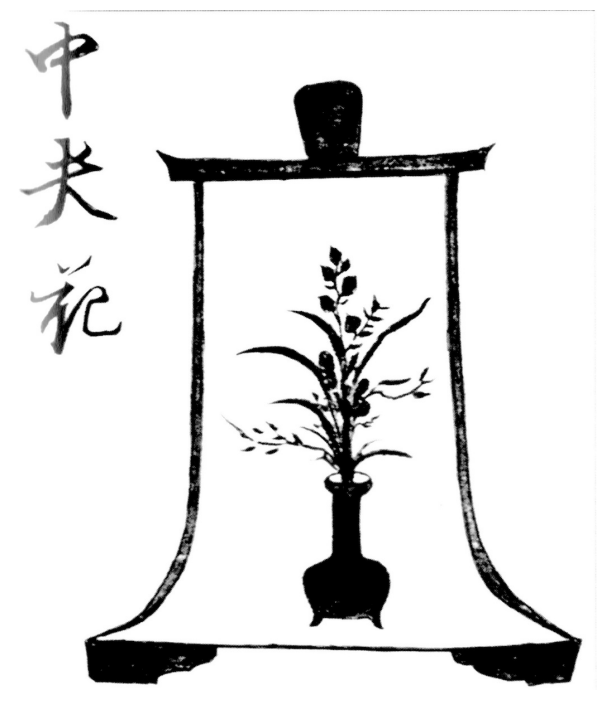

Figure 11. An example of the tatehana figure entitled Chuo-no-hana 中央花 or Central Flower by Sosei 宗清. Source: Sosei Kadensho 宗清花伝書 written in 1529.

A last example of a tatehana image to be studied here is the Sanhei-no-Hana 三へいの花 or Flower of Tree Vases (Figure 12), by Sen'ami 宣阿弥 found in Hanafu 花尔, a 16th century manuscript on ikebana with esoteric Buddhist text, written in 1552.

In this image, we see that three tatehana consist of three pine branches and some leaves. In a previous publication (2013), I indicated that this tatehana form is likened to the figure of Amida Sanzon 阿弥陀三尊 or three Buddhist divinities showing Amitabha Tathagata attended by Goddess of Mercy and Seishi Bosatsu or Mahasthamaprapta. There are scrolls representing Amida Sanzon drawn with Sanskrit characters as well as some examples of tatehana with themes fusing Shingon Mikkyo 真言密教 or Shingon esoteric Buddhism and Jodo 浄土 [Pure Land] Buddhism or a Buddhist practice with a particular focus on Amida Sanzon in the Hanafu manuscript. Traditionally, Amida Sanson is offered flowers, but not in the form of tatehana. However, it can be inferred from old documents that this tatehana representing Amida Sanzon was probably created in the early Muromachi period. Indeed, it was written in old documents in Koya 高野文書 that there was a fusion of esoteric Buddhism and Jodo Buddhism from the Kamakura period to the Muromachi period (Gorai, et al., 1979). That is to say, the idea of integrating esoteric Buddhism and Jodo Buddhism spread fast in Mt. Koya and had a great influence on other mountains and then became common everywhere in the Muromachi period (Gorai, 1998; Yamaori, 2000).

It can be inferred from the above that the unification of two different Buddhist sects (Tantric divinities of Shingon esoteric Buddhis sect and non-Tantric divinities of Jodo Buddhist sect) had gradually spread in the mountains and the esoteric Buddhist monk created new tatehana representing Amida Sanzon in the 16th century. There is a handcopied tatehana manuscript which Sen'ami monk handed down to an esoteric Buddhist 
monk, Ryuken, at the Hasedera Temple in Nara, attesting to that fact. This shows that Sen'ami was highly likely to be a mountaineering ascetic, because it was written in the manuscript of secrets (Hanafu) that Sen'ami became the pupil of one of the Ikenobo schools of Rokkaku-do in Kyoto. As there was a group of the Honzan 本山 branch (one of the main Shugen-do branches) related to the Tendai sect 天台宗, one of Buddhist sects near the pond in those days, we can conclude that this type tatehana, with the central axis connecting the heaven with the earth, was created by the shugen-ja.

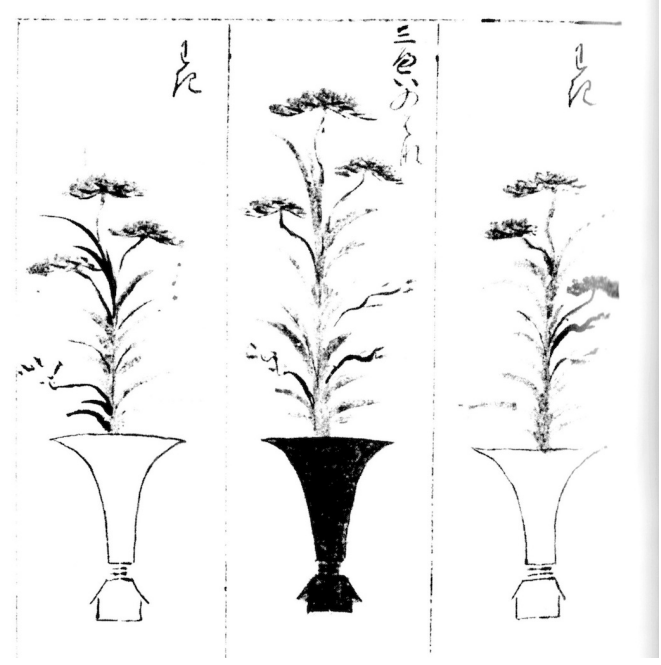

Figure 12 An example of the tatehana entitled Sanhei-no-Hana 三へいの花 (Flower of Tree Vases) by Sen'ami 宣阿 弥. Source: Hanafu 花了, (a 16th century manuscript on ikebana) written in 1552.

In summary, we found that in the late 15 th to the mid 16 th century, tatehana practitioners were almost all shugen-ja (ascetic monks or mountain priests). They had the basic idea that a tree is a sacred place where the Shinto divinities and the Buddhist divinities dwelled in after their descent from heaven (Murayama, et al., 1979). That is to say, a tree or a branch plays a pivotal role orientating the cosmic axis between the heaven and the earth. It is also a passage connecting the heaven with the earth as well as the original place for the life to return to (Miyake, 2004a). Bearing in mind the above, we are convinced that the tall central branch of tatehana was the boundary marker where the mountain divinity dwelt. In other words, the reason why these tatehana were created is that the practice was an act of offering flowers and branches to the mountain divinity, because the mountain was considered to be a mysterious and awesome place (Yuasa,1972; Nakayama, 2017). These also reflect the Japanese preBuddhist view of nature based on mountain worship (Ito \& Richie, 1967; Gorai, 1992b; Miyake, 2000; Yamaori, 2001).

4.3 The evolution of tatehana from the late Muromachi period (1338-1573) to the Azuchi-momoyama period (1573-1600)

After the transformation of the tatehana from a symbolic figure to a well-defined form during the Muromachi period, it was further transformed into a larger and more impressive tatehana form (Figure 13) from the late Muromachi period to the Azuchimomoyama period. After Shogun Ashikaga lost his political power, the provincial 
warlords took control of the affairs of government. During the period of National Reunification (1568-1600), two military heroes, Oda Nobunaga (1534-1582) and Toyotomi Hideyoshi (1536-1598), successively ruled Japan through numerous provincial warlords. It was a time for the strengthening of the powers of the feudal authorities and the full development of castle architecture (Yamato, 2000). Therefore, the large-sized tatehana was created by the appearance of the larger tokonoma in the castle. Now we will examine the close relationship between the large-sized tatehana and the larger tokonoma space.

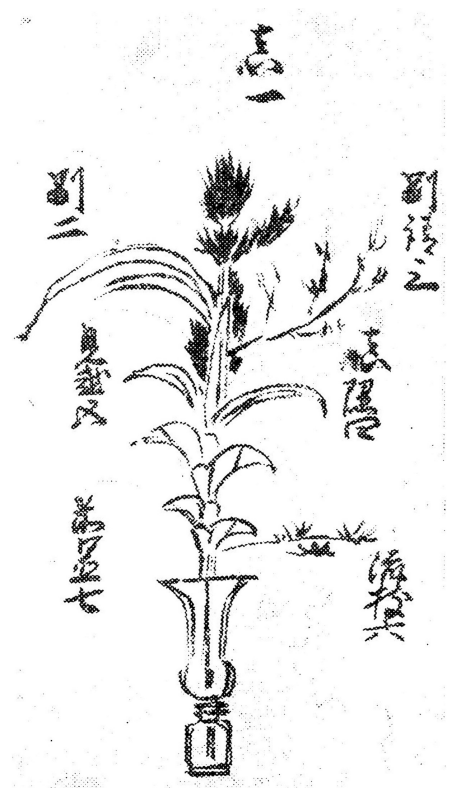

Figure 13. The large-sized tatehana in Kadensho 花伝書, Zashiki-Sogon-no- $Z u$ 座敷荘厳之圖 (a 16th century manuscript on ikebana) written by Ikenobo Sen'ei 池坊 専栄 in 1567. Source: Zoku Kado Kosho Shusei 2 [Collection of Writing on the Secrets of Way of Japanese Flower Arrangement Continued Vol.2] published in 1972.

Built in this time period, the Azuchi castle of Oda Nobunaga, the highest pavilion of the Azuchi castle (Tenshu-kaku 天守閣) which was seven stories high, was constructed by Nobunaga. The roof tiles were red in colour and were edged with gold leaf. Up to the third floor served as Nobunaga's living spaces. All the walls were painted stark white except for walls on the sixth floor which were painted a grave black and decorated with golden pillars. Pillars on the fifth floor were painted cinnabar red and under the handrails were carved dragons and killer whales, emblems of the imperial throne.

Records of the interior of Oda Nobunaga's Azuchi castle, indicate that the walls of the tokonoma space were completely covered in gold and painted over with bright wall paintings. In the shoin 書院 - a room used for reading, writing and studying - the background walls of gold were decorated with patterns and motifs in the castle colours such as vivid green, flashy blue and bright red. The motifs were of magnificent animals such as hawks, tigers, and eagles, as well as majestic plants such as pine trees, oaks, and peonies. It is inferred from the majestic motifs that the design of the Azuchi castle was based on those of ancient Chinese palaces. As a result of this change, the background of the tokonoma space went from being a simple setting to a colourful wall with intricate paintings (Nakayama, 2002a). The materials and colours used for the 
tatehana also changed (Zusetsu Ikebana Bunkashi [The Illustrated Cultural History of Ikebana], 1973). During the Azuchi-momoyama period the small-sized tatehana transformed in size, shape, and material into the large-sized one. However, the traditional practice and the basic form of the central branch with the central axis connecting the heaven with the earth did not change.

In the Jurakudai 聚楽第 castle of Toyotomi Hideyoshi, there was a main ceremonial hall called ohiroma 大広間. The highest of these was known as jodan-no-ma 上段の間 or the upper room. Within this hall, the ceremony of giving audience known as Taimen 対面 was held. This was a ceremony in which Toyotomi Hideyoshi gave audience to the warriors who pledged their allegiance to him. The Taimen ceremony played an important role in strengthening the feudal system with a public display of allegiance. As the name suggests, the floor level of the jodan-no-ma is a step higher than that of the other rooms. The hall consisted of jodan-no-ma or the upper room, chudan-no-ma 中段の間 or the middle room and gedan-no-ma 下段の間 or the lower room. This style of architecture allowed social standing to be differentiated by virtue of those seated in the lower levels being aware of a higher authority. From the records, we note that Toyotomi Hideyoshi was seated in the upper room, while the daimyo [feudal lord] and warriors prostrated themselves on the ground in the hundred-tatami floored lower room. In front of the jodan-no-ma, there was the larger tokonoma space. The largesized tatehana was situated in the larger tokonoma of the jodan-no-ma, a place symbolic of political power (Nakayama,1999).

\section{Transformation of the Tatehana into the Rikka in the Early Edo Period (17th century)}

During the Azuchi-momoyama period, Japanese arts and culture reached full maturity. Castle architecture introduced from Europe flourished and residences of warlords also became larger. So, changes occurred in the 'size' of the tatehana when it was shifted from the small shoin of Muromachi-dono 室町殿 or the residence of the Ashikaga shogunate to the large shoin of the castle of the provincial warlords. This shift resulted in a bigger version of tatehana being developed to suit the palatial interior of the castle of the provincial warlords. The tatehana was enlarged to match the size of the large tokonoma in the larger shoin of the castle. So, the small-sized tatehana drastically changed into the large-sized one in size, shape and material. However, it is not possible to separate the rikka from the tatehana in terms of traditional practice. The common features of both basic forms between tatehana (Figure 14a) and rikka (Figure 14b) are:

- The central branch stands vertically in the centre of a vase.

- The central branch is using the treetop of an evergreen.

- There are seven main branches.

- The role of main seven branches is almost same.

- The central branch is called shin (centre). 


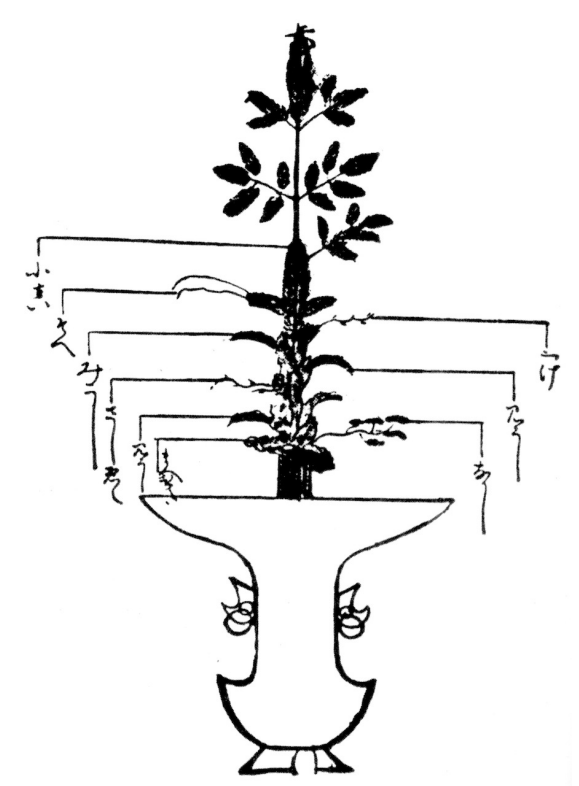

Figure 14a. The basic form of tatehana drawn by Ikenobo Sen'no 池坊専応. The character 真 (shin; central branch) is overlapped in the top of a central branch. The characters 小真 (shoshin; small central branch) are connected to the top of the short central branch by a line. Source: Sen'no Kuden 尃応口伝 (a 16th century oral traditions on ikebana) written in 1523.

Figure 14b. The basic form of rikka entitled Nanatsudogu-Shussho-no-Zu 七”道具出生之圖 [Figure of Birth of Seven Tools]. The character 心 (shin; central branch) is connected to the top of a central branch by a line. The characters 正 心 (shoshin; correct central branch) are connected to the top of the short central branch by a line. Source: Rikka Kun'mo Zui 立華訓蒙圖 彙 (a 17th century collection on ikebana) published 1696.

Later in the period, changes occurred in the rikka style. In the early Edo period the central branch of the rikka must stand vertically (Figure 15) as it was necessary to link the central axis between the heaven and the earth. But, in the mid Edo period the rikka with the curved central branch appeared. We will, now, discuss how the central axis 
connecting the heaven with the earth in the rikka was maintained with the curved central branch.

There is an example of rikka (Figure 16) in Shinkoku Heika Yodoshu 新刻瓶花容導集, which is a collection on ikebana by Ikenobo Senjo 池坊専定, published in 1797 . We see that the curved central pine branch called shin s is put upright into a vase and the small twofold pine branch stands vertically in the position of shoshin 正心 or correct central branch, linking the central axis between the heaven and the earth. We understand that this shoshin branch plays an important role in the rikka for maintaining the centre line between the heaven and the earth, because this type of rikka becomes rich in variation and increases the stately feeling by using the central branch with a dynamic curve. This concept also influenced seika or shoka styles established in the same period.

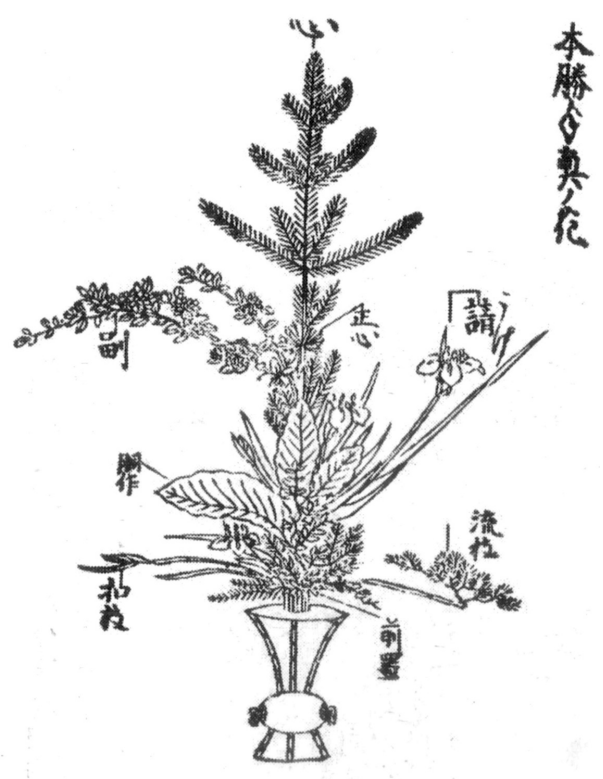

Figure 15. An example of the rikka with the vertical central branch entitled HongatteShin-no-Hana 本勝手真, 花. The character 心 (shin; central branch) is written in the top of a central branch. The characters 正心 (shoshin; correct central branch) are written in the top of the short central branch. Source: Kokon Rikka Daizen 古今立花大全 (a 17th century book on ikebana) by Juichiya Tauemon 十一屋太右衛門 published in 1683. In Kado Kosho Shusei 1 [Collection of Writing on the Secrets of Way of Japanese Flower Arrangement Vol.1], 1970. 


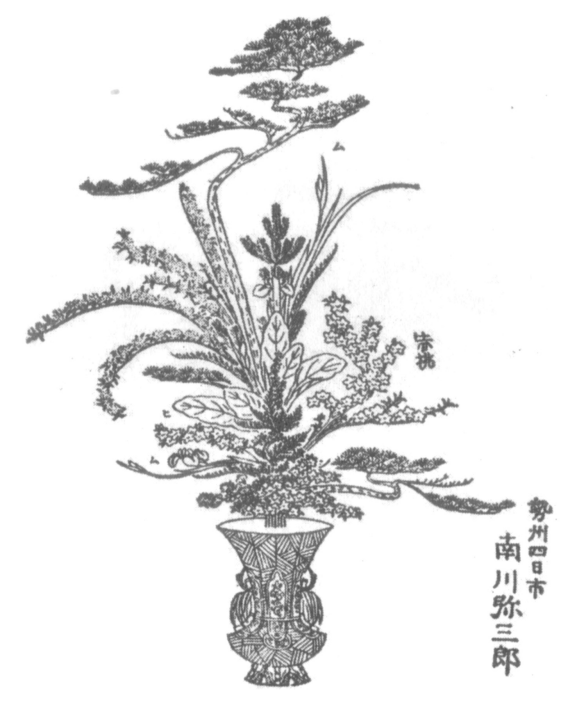

Figure 16. An example of the rikka with the curved central branch. We can see the small twofold pine branch stands vertically in the position of shoshin 正心. Other main branches became enlarged and increased the stately feeling all over the rikka by using the dynamic curved central branch called shin 心. Source: Shinkoku Heika Yodoshu 新刻瓶花容導集 (an 18th century collection on ikebana) by Ikenobo Senjo 池坊専定 published in 1797 .

\section{Appearance of Seika or Shoka in the Mid Edo Period (18th century)}

Rikka was still popular until the end of the Edo period. However, there gradually appeared many schools groping to create new ideas and new forms of ikebana. One of these new styles was known as seika or shoka. Many ikebana schools were established in the mid Edo period. It was written in The History of Ikebana by Kudo Masanobu (1989) that in the latter half of the 18th century, schools practicing the seika style such as Koryu 古流 established by Imai Sofu in 1770, Enshu 遠州 established by Shunjuken Ichiyo, Kodo 宏道 by Mochizuki Riunsai, as well as other schools such as Shofu 正風, Irie 入江, and Doku 独.

Why did many seika schools appear during the mid Edo period (18th century)? This is due to the fact that as peace continued through the Edo period (1603-1867) in Japan, the commoners were more involved in improving their quality of life. The extensive spread of ikebana among the ordinary people, was one of the results. Furthermore, the size of seika is smaller than rikka, but the characteristic of seika is simple, elegant and sophisticated. For that reason, seika coincided with the aesthetic sense called Iki 粋 or delicacy which was peculiar to the city of Edo (today Tokyo). From that time on, seika became very popular.

Here, we will compare the basic form of the three well-known ikebana schoolsIkenobo 池坊 school, Koryu 古流 school, Enshu 遠州 school一from their beginning to present day and see how they maintained the central axis between the top and the bottom in seika or shoka. First, we will mention the common features of three basic diagrams (Figure 17, Figure 18, Figure 19).

- The concept of the universe represented as a circle.

- The circle is divided into two parts: in-kata (yin) on the right and yo-kata (yang) on the left.

- The central branch (Ten or shin) is represented in curved form. 
- The central axis connecting the heaven with the earth is indicated by a dotted line drawing from the top to the bottom.

From the above, we understand that the traditional practice continuing from tatehana did not change, though each seika or shoka school has different theories and concept. For example, the Ikenobo school saw the theory of shoka as a simplification of the tatehana style, the Koryu school created a concept of seika focusing on free and fluid expression, and the Enshu school established a seika theory placing importance on the basic form of symbolic circle and curved line (Nishibori, 1942).
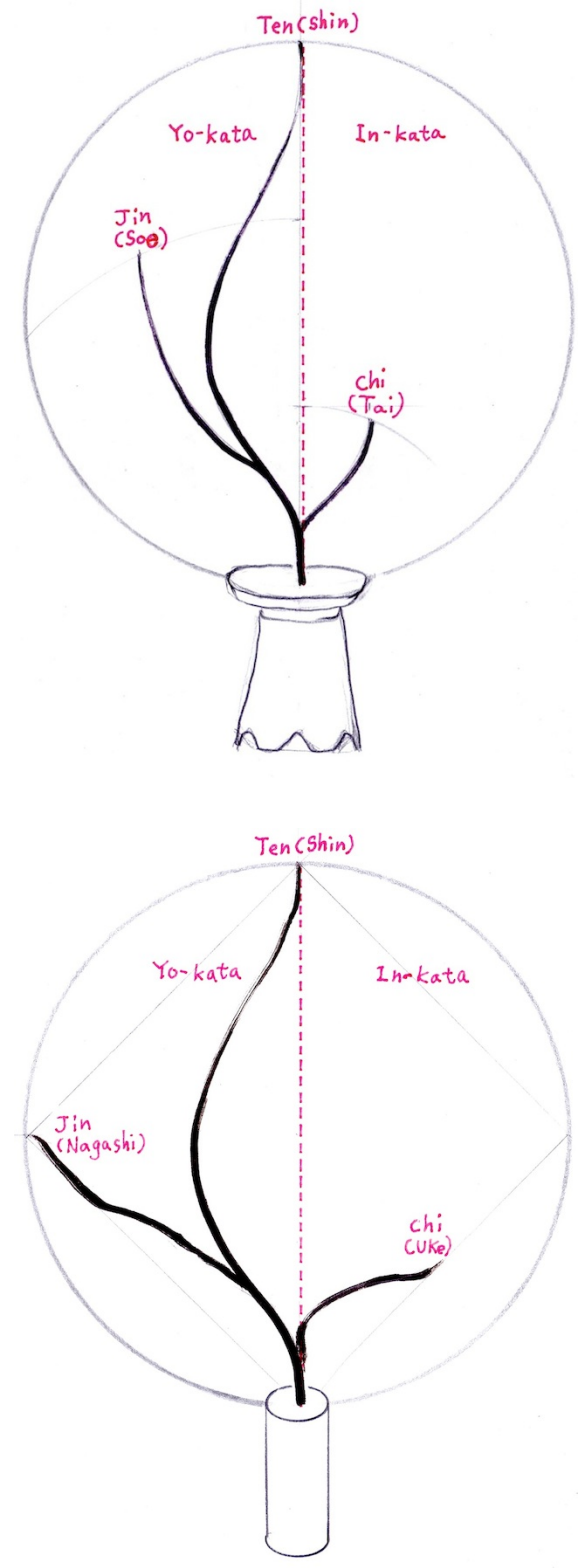

Figure 17. A diagram of shoka 生花 of the Ikenobo 池坊 school. The term shoka means small-sized ikebana and is only used by the Ikenobo school. The dotted red line indicates the central axis connecting the heaven with the earth. Source: The History of Ikebana by Kudo Masanobu published in 1989. This is hand copied by the author.

Figure 18. The diagram of seika 生花 of Koryu 古流 school. The dotted red line indicates the central axis connecting the heaven with the earth. Source: The History of Ikebana published by Kudo Masanobu in 1989. This is hand copied by the author. 


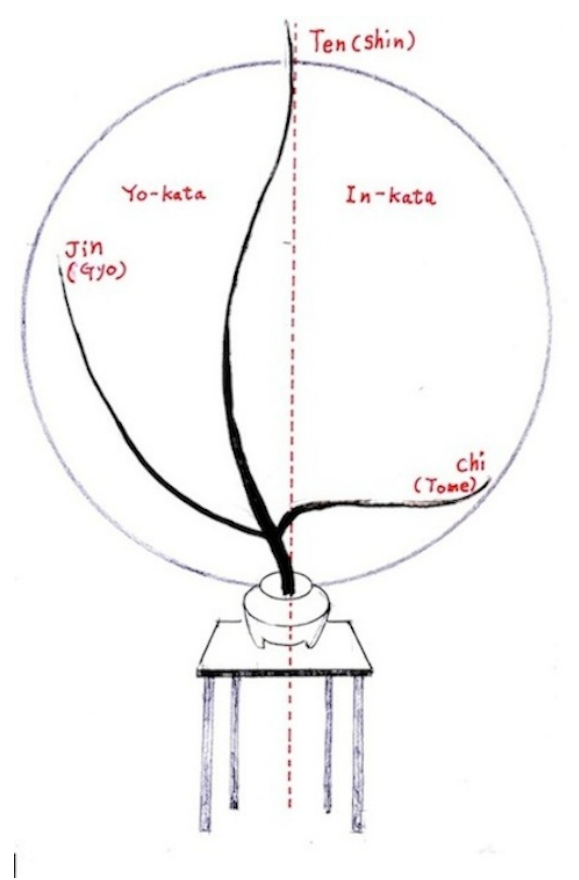

Figure 19. A diagram of seika 生花 of Enshu 遠州 school. The dotted red line indicates the central axis connecting the heaven with the earth. Source: The History of Ikebana by Kudo Masanobu published in 1989. This is hand copied by the author.

What about other schools? There is another famous school called Shogetsudo Koryu 松 月堂古流. The founder of the Shogetsudo Koryu school, Zeshinken Ichiro 是心軒一露 (1734-1780), an 18th century master of ikebana, devised a seika form based on a belief in five elements called Godai 五大 (地大 or earth, 水大 or water, 火大 or fire, 風大 or wind and 空大 or air) in esoteric Buddhism. The diagram of ikebana represents Gotai 五体 or 五躰 (the five parts of a body) based on Gorin-to 五輪塔 or Tower of Five Rings一地輪 or earth as rectangle, 水輪 or water as a circle, 火輪 or fire as a triangle, 風輪 or wind as a crescent and 空輪 or air as treasure ball (Figure 20). This basic form is drawn in a circle and comprises the five elements as a symbol of the universe. The main five branches have specific and different places are named shoka 正花, sorei 相令, tsuyo 通用, tai 体, and tome 留 (Nihon Sekibutsu Jiten [The Encyclopaedia of Japanese Stone Buddha], 1994).

From the above, we understand that Zeshinken Ichiro studied esoteric Buddhism and took 'five great thoughts' as five elements and assigned each of his principal stems to fit one of these elements. Nonetheless, the traditional practice continuing from tatehana did not change. Therefore, we can say that this seika form also has the central axis connecting the heaven with the earth. 


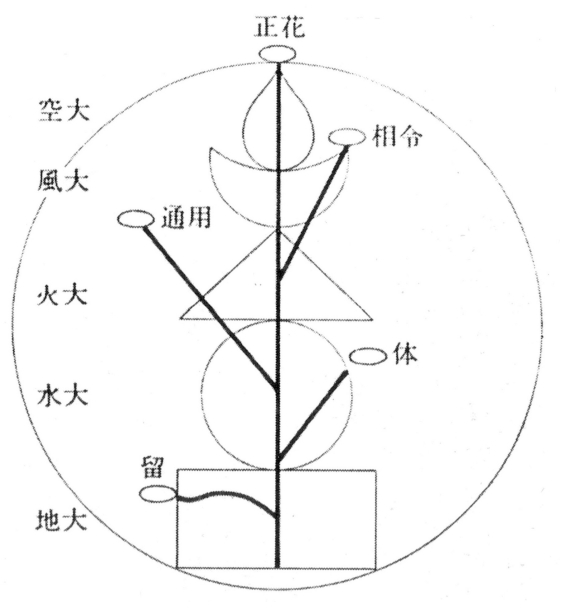

Figure 20. The diagram of Gotai-no-Hanagata 五躱の花形 or Flower Form of Five Parts of a Body. It symbolises Godai 五大 or five elements based on Gorin-to 五輪塔 or Tower of Five Rings and has the central branch with the central axis connecting the heaven with the earth. Source: Ikebana Sogo Daijiten いけばな総合大事典 [Ikebana General Encyclopaedia], 1980.

Another school is the Misho 未生 school. The founder of this school, Mishosai Ippo 未生 斎一甫 (1761-1824), created an ikebana philosophy based on the Yi-King 易経 or Book of Changes, using the principles of yin 陰 and yang 陽 and the theory taught by Lao-tzu 老 子 and Zhuang-zi 荘子. It was written in The History of Ikebana by Kudo Masanobu (1989) that with the Misho school, the ancient universal philosophy of squaring the circle was represented by a circle delineated within a square, with the latter's four corners touching the circle, which is then divided diagonally into two halves to create two triangles defined by Taoist thoughts as one being positive or yang, the other negative or yin. Then standing each triangle either upright or on its side, within their limits three stems of heaven, earth and humanity are placed, thus composing this distinctive form.

As an example of his work, there is the seika using chrysanthemums (Figure 21). This seika is based on the basic form of a triangle representing Ten 天 or Heaven, Chi 地 or Earth, and Jin 人 or Humanity. The central dotted line indicates the central axis connecting the heaven with the earth. So we can say that the traditional practice continuing from tatehana did not change. In the late Edo period, different schools of ikebana were established and ikebana came to have its own theory leading to its own style (Kajin Retsuden [A Series of Biographies of Ikebana Experts], 1984).

Presently, the important branches are the three main stems as a fulfilment of a concept of trinity in all schools the role of Ten 天 or Heaven, Chi 地 or Earth, and Jin 人 or Humanity in the universe. This idea owed its origin to the applied eight trigrams 八卦 and divination based on the Book of Changes 周易. At the same time, this form was based on the traditional practice continuing from tatehana that the Shinto divinities and Buddha descend from the sky to the top of a tree branch. 


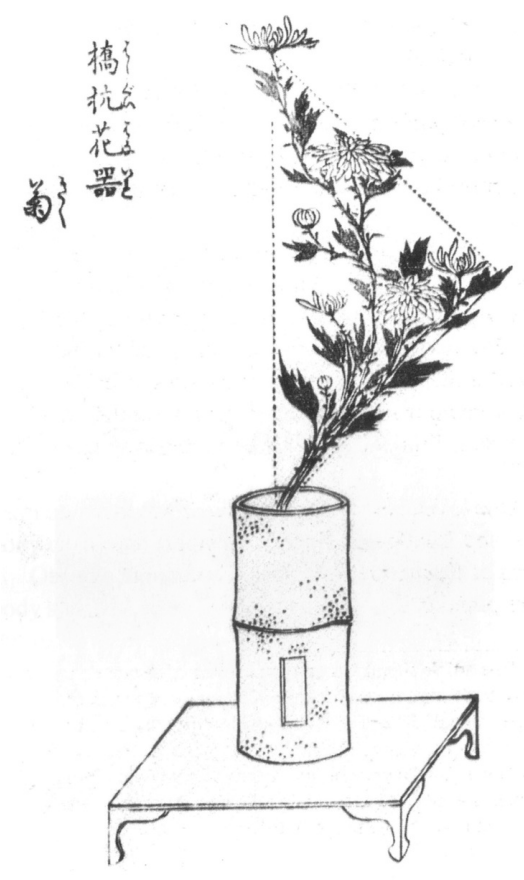

Figure 21. An example of seika using chrysanthemums. This seika is based on the basic form of triangle representing Ten 天 or Heaven, Chi 地 or Earth, and Jin 人 or Humanity. The central dotted line indicates the central axis connecting the heaven with the earth. Source: Ikebana Hyakuren 插花百練 by Mishosai Ippo 未生斎一甫 published in 1816.

\section{Conclusion}

Although tatehana is the original central guide for ikebana, it has, over time, been overshadowed by rikka. However, it is important to understand and bring the essential principle of tatehana back to its rightful place - the centre for ikebana. Tatehana was born from ancient Japanese native beliefs, that big trees are places where the mountain divinities dwell. They move from this dwelling down to the erected scared trees. Traditions say that the big trees in the deep mountains were brought down to villages and were erected as wooden poles, and then became kami (the Japanese folk divinity) in Suwa District, Nagano Prefecture. After the cutting of the big trees for the Onbashira-sai festival in the forest of Shimosuwa and Mt. Yatsugatake in Nagano Prefecture, the mountain dwellers participating in the Onbashira-sai festival brought the tallest part of the tree crown to the house as a memorial object and then put it into a flower vase or placed it in the tokonoma space.

It has long been thought that tatehana was one of the geneses of ikebana. However, it can be inferred from the above-mentioned customary practice that tatehana began from erecting the tallest part of the tree crown of a big tree used in the rituals of the mountain divinity. It could be also deduced by more detailed discussion of tatehana that it reflected the worship of the sacred mountains and represented the central axis of a mountain connecting the heaven with the earth. As a result, rikka was developed from tatehana, and seika or shoka evolved from rikka. From there, many different arrangements evolved following seika or shoka by using not only trees but also flowers 
like Japanese iris (ayame/shobu 菖蒲) and leaves like Aspidistra elation (haran 葉蘭) emerge (Nakayama, 2002b).

We conclude that in the Muromachi period, the starting point of ikebana, tatehana was used to place the cut branch taken from a big tree upright into a vase and had the basic form of the central branch with the central axis connecting heaven with the earth and was based on the traditional belief that Shinto divinities and the Buddha descend from the sky to the top of a big tree. In the Azuchi-momoyama period, although the smallsized tatehana transformed in size, shape, and material into the larger work, the traditional practice and the basic form did not change. In the early Edo period rikka maintained this basic form and traditional practices. In the late Edo period this basic form and traditional practices continuing from tatehana were handed down from rikka to seika or shoka. Today ikebana is still being performed using the basic form and the traditional practices highlighted in this article.

\section{References}

Britannica Encyclopaedia (2014). Tokyo: Britannica Japan Co., Ltd.

Gorai, S. (1992a). Yama no Shukyo-Shugen-do Kogi [Mountain Religion-The Lecture of Shugen-do]. Tokyo: Kadokawashoten.

Gorai, S. (1992b). Senzokuyo to Haka [Memorial Service for Ancestor and Grave]. Tokyo: Kadokawashoten.

Gorai, S. (1998). Zoho—Koya Hijiri [An enlarged edition—Koya Buddhist Itinerant Preacher]. Tokyo: Kadokawashoten.

Gorai, S. (Ed.). (1979). Koyasan to Shingon Mikkyo no Kenkyu [The Study of Mt. Koya and Shingon Esoteric Buddhism]. The History of Mountain Religion Study Series: Vol. 3. Tokyo: Meichoshuppan.

Gorai, S. (Ed.). (1980a). Kinki Reizan to Shugen-do [The Sacred Mountains of Kinki District and Shugen-do]. The History of Mountain Religion Study Series: Vol. 11. Tokyo: Meichoshuppan.

Gorai, S. (Ed.). (1980b). Shugen-do no Bijutsu Geino Bungaku 1 [The Art, Performing Arts and Literature on Shugen-do 1]. The History of Mountain Religion Study Series: Vol. 14. Tokyo: Meichoshuppan.

Gorai, S. (Ed.). (1981a). Shugen-do no Bijutsu Geino Bungaku 2 [The Art, Performing Arts and Literature on Shugen-do 2]. The History of Mountain Religion Study Series: Vol. 15. Tokyo: Meichoshuppan.

Gorai, S. (Ed.). (1981b). Shugen-do no Denshobunka [The Oral Traditional Culture of Shugen-do]. The History of Mountain Religion Study Series: Vol. 16. Tokyo: Meichoshuppan. 
Malaysian Journal of Performing and Visual Arts, Volume 4, 2018

Gorai, S. (Ed.). (1982). Yoshino-Kumano Shinko no Kenkyu [The Study of the Faith of Yoshino and Kumano]. The History of Mountain Religion Study Series: Vol. 4. Tokyo: Meichoshuppan.

Hanawa, H. (1899). Gunsho Ruiju [Japanese Historical Classified Documents]. Tokyo: Keizaizasshisha.

Hanawa, H. (1911). Zoku Gunsho Ruiju [Japanese Historical Classified Documents Continued]. Tokyo: Keizaizasshisha.

Hojo, A. (1977). Ikebana Jinbutsushi [History of Personage on Ikebana]. In Collected Works on Ikebana of Akinao Hojo Vol.2. Tokyo: Shibundo.

Hosokawa, M. (1985). Ikebana Hando Bukku [Guide of Japanese Flower Arrangement]. Tokyo: Tokyobijutsu.

Ikebana Sogo Daijiten [Ikebana General Encyclopaedia] (1980). General Editor: Okada, K; Kudo, M; Yukawa, O. Tokyo: Shufunotomosha.

Ito, T. \& Richie D. (1967). Nihon no Dento 1-Ikebana [Traditional Art of Japan 1Ikebana]. Tokyo: Tankoshinsha.

Kado Kosho Shusei 1-5 [Collection of Writing on the Secrets of Way of Japanese Flower Arrangement Vol.1-5]. (1970). Kyoto: Shibunkaku.

Kajin Retsuden [A Series of Biographies of Ikebana Experts]. (1984). Tokyo: Kodansha.

Kamata, S. (2002). Kegon no Shiso. [The Thought of Kegon]. Tokyo: Kodansha.

Kisoshiki-Batsuboku-Unzai-Zue [The Document of Picture Depicting the Logging and the Log Hauling of Kiso]. (1954). Nagano: Nagano Regional Forestry Office.

Kudo, M. (1987). Ikebana no Michi [Way of Japanese Flower Arrangement]. Tokyo: Shufunotomosha.

Kudo, M. (1989). The History of Ikebana. Tokyo: Shufunotomosha.

Miyake, H. (1991). Shugen-do-Yamabushi no Rekishi to Shiso. [The Shugen-do-The History and Philosophy on Yamabushi, Itinerant Mountain Buddhist Monks]. Tokyo: Kyoikusha.

Miyake, H. (2000). Nihon no Minzokushukyo [Japanese Folk and Religion]. Tokyo: Kodansha.

Miyake, H. (2003). Shugen-do-Sono Rekishi to Shugyo [The Shugen-do-Its History and Ascetic Practice]. Tokyo: Kodansha.

Miyake, H. (2004a). En-no-Gyoja to Shugen-do no Rekishi [En-no-Gyoja, One of the Most Celebrated Mountain Sages and the History of Shugen-do]. Tokyo: Yoshikawakobunkan. 
Miyake, H. (2004b). Reizan to Nihonjin [The Sacred Mountain and the People of Japan]. Tokyo: NHK Books.

Murayama, S. (Ed.). (1979). Hieizan to Tendai Bukkyo no Kenkyu [The Study of Mt. Hiei and Tendai Buddhism]. The History of Mountain Religion Study Series: Vol. 2. Tokyo: Meichoshuppan.

Murayama, S. (1992). Nihon Onmyodoshi Sosetsu [Japanese Yin-Yang History Review Paper]. Tokyo: Niwashobo.

Nagahara, K. (1977). Nihon no Rekishi 10—Gekokujo no Jidai [Japanese History Vol. 10 - The Period of the Low Overturning the High]. Tokyo: Chuokoronsha.

Nakayama, M. (1999). Origins of Ikebana Philosophy. Penang: The Asian Centre.

Nakayama, M. (2001). Tatehana to Shichishi-to [Standing Flower and Seven Branched Sword]. Penang: The Asian Centre.

Nakayama, M. (2002a). Ikebana no Kigen-Tatehana to Shichishi-to [The Origin of Ikebana-Standing Flower and Seven Branched Sword]. Kyoto: Jinbunshoin.

Nakayama, M. (2002b). Hana to Wabi no Kokoro [Ikebana and the Heart of 'Wabi']. Penang: The Asian Centre.

Nakayama, M. (2005). Nana to Nihonjin [Number Seven and the people of Japan]. Penang: The Asian Centre.

Nakayama, M. (2013). 500 Years of Ikebana. Penang: The Asian Centre.

Nakayama, M. (2017). Sacred Trees: The Root of Ikebana. Penang: The Asian Centre.

Nihon Fuzokushi Jiten [The Encyclopaedia of the History of Japanese Manners and Customs]. (1979). Tokyo: Kobundo.

Nihon Sekibutsu Jiten [The Encyclopaedia of Japanese Stone Buddha]. (1994). Tokyo: Yuzankaku.

Nishibori, I. (1942). Nihon no Kadoshi [The History of Japanese Flower Arrangement]. Osaka: Sogensha.

Nishibori, I. (1967). Nihon no Ikebana [Japanese Flower Arrangement]. Kyoto: Kawarashoten.

Ooi, M. (1968). Ikebana no Rekishi [The History of Japanese Flower Arrangement]. Tokyo: Shufunotomosha.

Tanaka, J. \& Okada, K. (1981). Sendenshou Jo, Ge [The Book of the Secrets on Ikebana Vol. 1, 2]. Kyoto: Nihonkadosha. 
Togawa, A. (1980). Dewa Sanzan to Tohoku Shugen no Kenkyu [The Study of Dewa Three Mountains and Shugen in the North-Eastern Parts of Japan]. The History of Mountain Religion Study Series: Vol. 5. Tokyo: Meichoshuppan.

Wakamori, T. (1988). Yamabushi-Nyubu, Shugyo, Juho [The Yamabushi, Itinerant Mountain Buddhist Monks-Pilgrimage to the Peaks, Ascetic Practice, Magic]. Tokyo: Chuokoronsha.

Yamaori, T. (1991). Kami to Hotoke-Nihonjin no Shukyokan [Shinto Divinity and Buddha-The Japanese Religious Views]. Tokyo: Kodansha.

Yamaori, T. (1993). Nihon Bukkyo Shiso no Genryu [The Source of Japanese Buddhist Thought]. Tokyo: Kodansha.

Yamaori, T. (1994). Bukkyo Shinko no Genten [The Origin of Buddhist Belief]. Tokyo: Kodansha.

Yamaori, T. (2000). Nihonjin to Jodo [The people of Japan and Pure Land]. Tokyo: Kodansha.

Yamaori, T. (2001). Bukkyo Minzokugaku [Buddhist Folklore]. Tokyo: Kodansha.

Yamato, S. (2000). Shiro to Goten [Castle and Palace]. Nihon no Bijutsu [Japanese Art], No.405.

Yuasa, Y. (1972). Kamigami no Tanjo [The Birth of Japanese Divinities]. Tokyo: Ibunsha.

Zoku Kado Kosho Shusei 1-5 [Collection of Writing on the Secrets of Way of Japanese Flower Arrangement Continued Vol.1-5]. (1972). Kyoto: Shibunkaku.

Zusetsu Ikebana Bunkashi 1-3 [The Illustrated Cultural History of Ikebana Vol.1-3]. (1973). Tokyo: Shufunotomosha. 